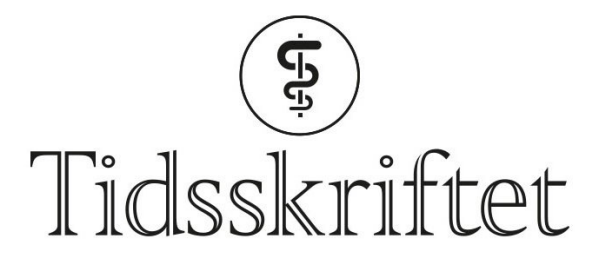

DEN NORSKE LEGEFORENING

\title{
Kan stress gi grått hår?
}

FRA ANDRE TIDSSKRIFTER

HAAKON B. BENESTAD

Universitetet i Oslo

I en musestudie fikk mus som ble påført smerte, et større innslag av fargeløse hår.

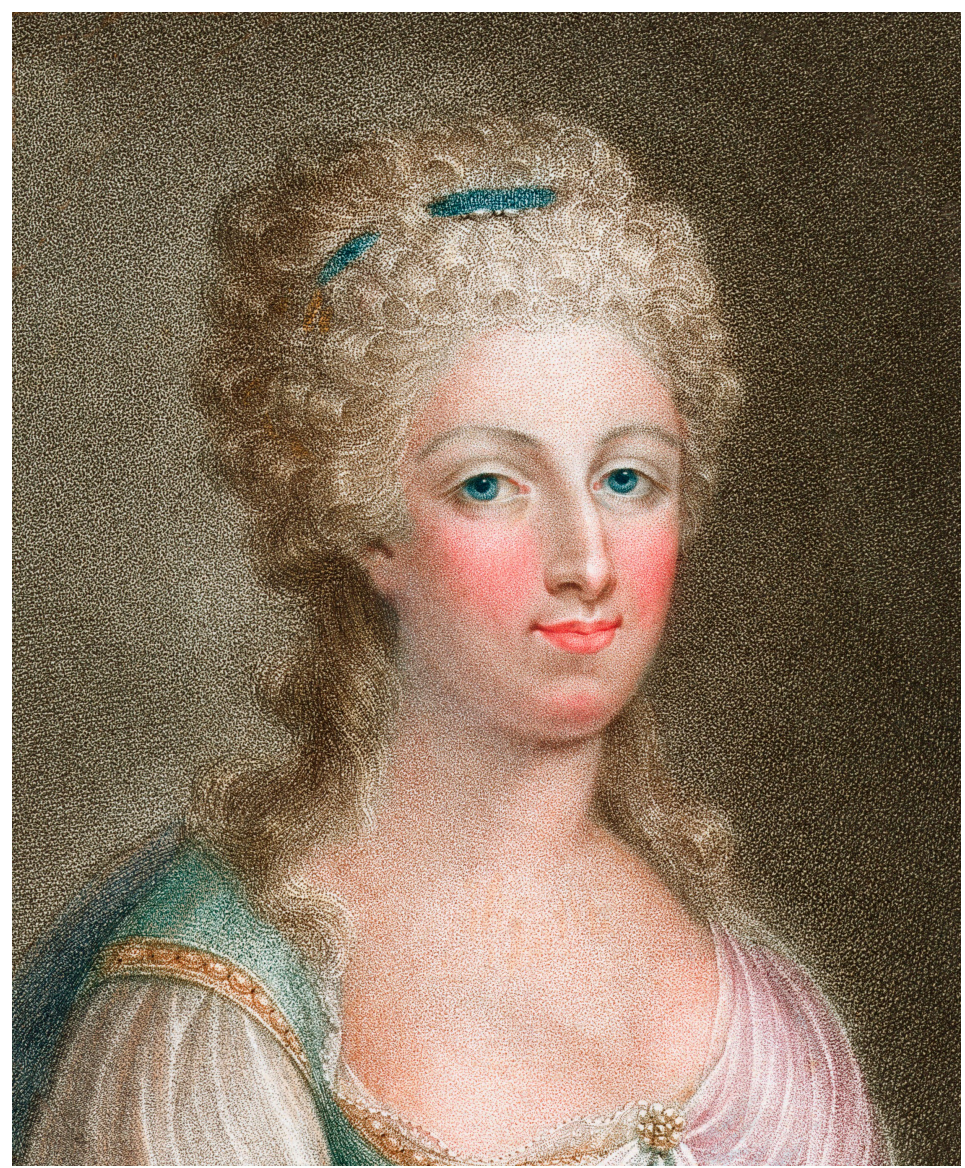

Illustrasjon: IanDagnall Computing/Alamy Stock Photo

Det sies gjerne at dronning Marie Antoinette ble grå i håret natten før hun ble halshugget av de revolusjonære. Skyldtes dette stress eller hårvask kvelden før? En ny musestudie tyder på at stress kan fremskynde gråning av hår, det vil si øke innslaget av hvite, fargeløse hår (1).

Hodebehåringens farge bestemmes av melanocytter, som overfører ulike blandinger av brunsvart eumelanin og rødgult feomelanin til hårene. Melanocyttene dannes fra melanocyttstamceller i en utposning på hårsekken, som er en stamcellenisje, og som er sympatisk innervert. Stamcellene vandrer langs hårsekken under hårets vekstfase, modnes 
til melanocytter i hårsekkpapillen og avgir melanin til håret. De utvandrete cellene forsvinner under hårets degenerasjonsfaser og hvilefaser. Men mange melanocyttstamceller er normalt igjen i nisjen sin og kan ta opp igjen vandringssyklusen under neste vekstfase.

I den nye studien ble mus påført kronisk smerte. Smertestimulus førte til flere hvite hår i vekstfasen, mens mildere stressorer ga grå innslag i den mørke musepelsen først etter 3-5 vekstfaser. Smerten førte til at hårsekknisjen for melanocyttstamceller ble tømt.

Melanocyttstamceller har adrenerge $\beta 2$-reseptorer, og en kraftig og vedvarende sympatisk aktivering fikk stamcellene til å proliferere svært hurtig og vandre sin vei, vekk fra nisjen. Dermed ble det ingen nye melanocytter og ny melaninproduksjon til nye hår. Alternative mekanismer, slik som immunstimulering, kortikosteron, noradrenalin eller adrenalin fra binyrebarken, ble utelukket. Blokkering av den sympatiske innervasjonen av hårsekkene og opioidbehandling forhindret smerteaktivert gråning, mens akutt sympatikusaktivering, uten stress, satte i gang gråning.

- Det er godt kjent at håret kan fremstå som grått nærmest over natten, men man kjenner ikke hvilke patofysiologiske mekanismer som ligger bak, sier Tone Kristin Bergersen, som er hudlege og førsteamanuensis ved Institutt for klinisk medisin, Universitetet i Oslo.

- Den mest aksepterte hypotesen er at fenomenet må betraktes som en akutt og diffus form for alopecia areata, som er en immunologisk og oftest forbigående tilstand som kan utløses av stress. Ved alopecia areata vil pigmentert hår falle ut spontant, mens grå hår kan bli sittende og komme tydeligere frem. Hår som vokser ut etter en episode med alopecia areata, kan mangle pigmentering. Funnene i denne musestudien kan passe med en slik forklaring, sier Bergersen.

\section{LITTERATUR:}

1. Zhang B, Ma S, Rachmin I et al. Hyperactivation of sympathetic nerves drives depletion of melanocyte stem cells. Nature 2020; 577: 676-81. [PubMed][CrossRef]

Publisert: 19. oktober 2020. Tidsskr Nor Legeforen. DOI: 10.4045/tidsskr.20.0655

(C) Tidsskrift for Den norske legeforening 2020. Lastet ned fra tidsskriftet.no 